\title{
3 Definitions, theory, and research making in rural Sweden
}

This chapter has four sections. The first section offers a number of basic definitions in rural criminology used in this book. In some cases, several definitions are put forward instead of assuming a single definition. The case of "rural" provides an example of this approach. The second section is devoted to a number of theories that provide the theoretical basis for the book. Each theory is introduced in a way that highlights its importance for rural studies, particularly on crime, perceived safety, and crime prevention. In the third section, the chapter takes a practical turn and focuses on the making of research on crime and safety in rural areas. This section discusses issues of measurement and data quality that are used later in the book. Finally, in the fourth section Sweden is introduced as study area.

\section{Definitions}

The definitions set out a basis for the concepts referred to throughout the book.

\section{Rural, rurality}

There is common agreement that any attempt to obtain a common definition of rural (rural areas, rurality) might not be useful or even possible. ${ }^{1}$ There are several reasons why a blunt template around the definition of rural should be avoided, such as:

Not all rural communities are alike, and defining the concept rural is subject to much debate.

(DeKeseredy, 2015; Donnermeyer, 2012; Websdale \& Johnson, 1998)

The broad category "rural" is obfuscatory ... as intra-rural differences can be enormous and rural-urban similarities can be sharp.

(Hoggart, 1990, p. 245)

Rurality is a contested concept that remains somewhat arbitrary and open to debate. 
Rural areas are not only a residual to urban areas: just because it isn't urban doesn't mean it must be rural.

(e.g., Bosworth \& Somerville, 2014; Groves, 2011)

Rural areas are in constant transformation (Woods, 2005, 2011), so any definition of what rural might be depends on the time, the space, and other contexts. The search for a singular definition of rural is illusory.

(Halfacree, 1993)

Traditional images of "rural" compress the richness of rurality into a homogenizing template, neglecting the existence of "other rurals" (Philo, 1997: 22) and images that embody different socialities, sexualities, ethnicities, and subjectivities.

(Owen \& Carrington, 2015)

The term "rural" is generally employed to describe non-urban or peripheral regions (Barclay, Scott, Hogg, \& Donnermeyer, 2007, p. 3). Rural is composed of a diverse set of communities with different characteristics and needs that share a number of qualities and challenges (Ceccato \& Dolmén, 2013, p. 90). In Sweden, there are different definitions of "rural". The one adopted in this book breaks rural areas in two types: Remote Rural (RR) and Accessible Rural (AR) (Swedish National Rural Development Agency, 2008). This definition reflects the municipalities' population size and accessibility - two relevant components to an area's criminogenic conditions (For more details see the last section of this chapter). What do these areas have in common? What does it matter to crime and community safety?

1 Rural has a spatial dimension. Hogg and Carrington (1998) suggest that rural can be defined in terms of demography, population size, density, and geographical isolation (Halfacree, 1993; Woods, 2005, 2011). Remoteness is also associated with rural, but as Barclay et al. (2007) observe, the exact distance that designates what places are remote and the exact number of people that distinguishes rural are on a sliding scale. The geographical dimension also involves the economic profile of an area, land use, and productive systems (Woods, 2005). The spatial dimension may be attributed by those who live there or by outsiders through intuitive understandings of rurality. For crime and safety, the spatial dimensions of rural have implications for both research and practice. Crime levels and the nature of crimes may vary, as well as ways that they have to be combated through crime prevention measures. See examples in Chapters 5-6 and 8-14 of this book.

2 Time is an important dimension when defining rural. Time is as fundamental to the conception of rural as the spatial dimension is. As well observed by Thrift (1996, p. 47), time and space do not exist alone. Time provides a reference, such that invisible changes might be happening in rural areas but as yet may not be noticeable to the naked eye (Ilbery \& Bowler, 1998; Marsden, 1998; Shortall \& Warner, 2012; Woods, 2011). "[Rural] space 
should be seen as a process and in process: all space is practiced, all space is place." In this respect, any investigation into rural space requires a strongly temporal contextual approach that makes it possible to analyze potential entanglements at play (Halfacree, 2006). For crime, the temporal dimension is crucial, as crimes may not happen if their basic conditions are not in place (Brantingham \& Brantingham, 1984; Cohen \& Felson, 1979; Rhodes \& Conly, 1981; Wikström, Ceccato, Hardie, \& Treiber, 2010).

3 Context matters when defining rural. The importance of context in rural is also suggested by Halfacree (2006, p. 45), as the author indicates that any analysis of rural space must always be sensitive to the issue of geographical specificity. This argument has been reinforced by many other scholars in the field of rural studies (Woods, 2005; Yarwood \& Edwards, 1995), some by focusing on historical context (Mahon, 2007), the social, cultural, and economic change contexts (Holloway \& Kneafsey, 2000), regulatory contexts (Marsden, 2008), and geographical ones, from the village up to the national levels (e.g., Barclay et al., 2007; Ceccato \& Dolmén, 2011; Scorzafave, Justus, \& Shikida, 2015; Weisheit \& Donnermeyer, 2000). Focusing on the specificity of a particular context for crime and safety in rural areas requires a new method of interpretation, one that avoids generalization and allows for the richer, more nuanced, and perhaps more meaningful knowledge gained by investigating a particular case study. For practice, context is fundamental to crime prevention, which should be tailored to each local context, avoiding "one-size-fits-all" solutions.

4 Rural-urban interactions. The interactions between urban cores and their hinterland are fundamental to understand the contemporary conception of rurality, not only in economic and political terms (van Leeuwen, 2010) but in relation to people's daily mobility and communication patterns as well as lifestyle changes. These interactions and interdependences are not something new (for a review of Von Thunen's and Christaller theories, see Melamid, 1967) but have fairly recently been recognized as important to understand the dynamics of crime across regions (Ceccato, 2007; Ceccato \& Haining, 2004; Weisheit, Falcone, \& Wells, 2006; Weisheit, Wells, \& Falcone, 1994).

Table 3.1 Some rural-urban dichotomies

\begin{tabular}{lll}
\hline Author & Urban category & Non-urban category \\
\hline Becker & Secular & Sacred \\
Durkheim & Organic solidarity & Mechanical solidarity \\
Maine & Contract & Status \\
Redfied & Urban & Folk \\
Spencer & Industrial & Military \\
Tonnies & Gesellschaft & Gemeinschaft \\
Weber & Rational & Traditional \\
Bell & Criminogenic & Idyll \\
Bell, Philo & Normal & Strange, horror \\
\hline
\end{tabular}

Source: adapted from Reissman (1964) in Halfacree (1993, p. 25). 
5 Rural depends on the eye of the beholder. The relativism of the concept of rural is apparent in the diverse understandings of rurality, some emphasizing cohesiveness, informality between locals, or idyllic images, others revealing the dark side with retrograde values that allows a process of othering and may be associated with peculiar behavior and horror (Bell, 1997; DeKeseredy, Muzzatti, \& Donnermeyer, 2014; Donnermeyer, Jobes, \& Barclay, 2006; Philo, 1997b; Scott, Carrington, \& McIntosh, 2012; Tönnies, 1887). Rural possesses a dimension of reflexivity (Giddens, 1991): what is rural depends on those who observe and produce it. The dichotomy of perceptions within rural may be relatively new, but for some time it has defined urban versus rural. Dichotomies related to rural-urban environments influenced some of the early studies of rural communities (Halfacree, 1993) and are also noticeable in more recent rural studies (Table 3.1).

Research on crime and community safety can take advantage of these commonalities and make them visible by developing cases, that is, particular studies, and promoting the application of comparative research that can shed further light on rurality in its own right.

\section{Rural space}

'Space does not 'just exist,' waiting passively to be discovered and mapped, but is something created in a whole series of forms and at a whole series of scales by social individuals"; space is not one but rather a great diversity of "species of space" (Crang \& Thrift, 2000, p. 3). In a few chapters of this book, "spaces" are the spaces experienced and/or perceived by people in rural areas. In other chapters, space is the domestic environment, which can be a safe realm but may be a place of violence. In yet other chapters, rural spaces are arenas of conflict and resistance of imposed macro-scale political and economic social orders in the wilds of northern Sweden. Yet, as this book progresses, the discussion will suggest that rural space is "more than simply the sum of separate relations that comprise its parts" (Smith, 1984, p. 83), tied up with different time frameworks and contexts.

Traditionally, Frey and Zimmer (2001) suggests that there are three elements which can help distinguish an area as "urban" or "rural." First, there is the ecological element, which includes population and density. The second element is economic, which refers to the function of an area and the activities that take place (this tends to increase the number of people commuting into the area and country contexts). The third element which distinguishes urban from rural areas is the social character of an area. Differences appear, for example, in the way urban and rural people live, such as people's behavioral characteristics and values.

Halfacree's model of rural space $(2006$, pp. 48, 52) is advertised as one "that can be applied to all rural places" yet allows for distinctiveness of contexts. Halfacree's architectural model for rural space is, according to this author, about realizing "what is already there," rather than imposing a new understanding of it. 


\section{Introduction}

The first part of his model is composed of what he calls rural localities that are inscribed by relatively unique spatial practices, either by production or consumption activities. The second part refers to the formal representations of the rural and how "rural" is framed, for instance, within the production process, by capitalist interests, bureaucrats, or politicians; in this case, how the rural is commodified in exchange-value terms. Finally, the third part consists of everyday lives of the rural and, as such, is constituted by incoherent and fractured experiences of the rural. These incorporate individual and social elements ("culture") in their cognitive interpretation and negotiation of the rural; in a planning language, this provides a basis for a bottom-up perspective of the rural.

\section{Rural community}

One modern definition of rural communities is "places with small population sizes/ densities, areas where people are more likely to know each other's business and come into regular contact with each other" (Websdale \& Johnson, 1998, p. 102). Also, according to DeKeseredy (2015), they are locales that exhibit variable levels of collective efficacy. The term collective efficacy, although generated originally with urban settings in mind, means "mutual trust among neighbors combined with a willingness to act on behalf of the common good, specifically to supervise children and maintain public order" (Sampson, Raudenbush, \& Earls, 1997, p. 1). According to this, rural communities would tend to show these features more often than any other type of environment. Chapters 12-14 show how these features are expressed in the Swedish context by promoting individual and group mobilization to prevent crime and promote safety principles.

Actions, meanings, and practices are also part of the definition of community as proposed by Liepins $(2000$, p. 30). For the author, a community is a place in which "entities ... are produced through relations and interactions between actors and intermediaries which are linked through networks." Spaces and structures relate to the physical and non-physical dimensions, for they enable "the materialization of meanings" and impact on "how practices can occur." Communities are therefore "temporarily and locationally specific terrains of power and discourse." What is particularly positive about this definition is that it goes beyond the space-related definitions of communities that have dominated rural research and defines rural communities as worthy of analysis in their own right.

Up to now, rural communities have been identified as different from urban areas (Rogers, Burdge, Korsching, \& Donnermeyer, 1988), which fits into the contrasting notion of urban and rural communities that was previously in vogue. These conceptions drew heavily on Tönnies' (1887) gemeinschaft and gesellschaft, the former being associated with communities with strong social ties, socially intimate and characterized by strongly shared norms imposing social order. The latter type of community was characterized by the individualistic, formal, and rational. Individuals' standards of behavior are negotiated following rules and contractual obligations and may be expressed in social relations that are more superficial, leading to social isolation (Donnermeyer, 2007; Tönnies, 1887). This is the 
urban-rural dichotomy that has guided and perhaps dictated the way communities have been framed in twentieth century research. However, there is reason to believe that contemporary social interaction challenges the tyranny imposed by Tönnies' "black and white" definition of gemeinschaft and gesellschaft and perhaps makes obsolete any type of traditional notion of community. In a digital era, community takes a virtual form and is a much more fluid concept than any other conception of rural community so far, while still connecting with the gesellschaft notion of community and individualism. Individuality comes as a result of the fact that people are given more "informed choices" (Giddens, 1991).

The idea of online community has become increasingly widespread. Fernback (2007) found that the concept of "community" in cyberspace is one of convenient togetherness without real responsibility or commitment ... that community is an evolving process, and that commitment is the truly desired social ideal in social interaction, whether online or offline. Yet cyberspace can also build on existing communities and social ties. Lambert (2013, p. x) suggests that "community - no matter the setting - is grounded in belonging, understanding, in plurality."

When relationships are built and strengthened through storytelling, people feel welcomed and valued, and civic participation is enhanced. There is nothing new in this. What is new is the digital. Indeed, we're awash in such stories.... We're telling it as it is. As we are experiencing it. We are forming communities around our stories.

In the summer of 2014, people in Sweden turned their eyes to the countryside, as a fire spread over an area of $65 \mathrm{~km}$ of forest in Västmanland County. The media portrayed the experiences of individual families and their vulnerability in this disaster, which cost more than one billion Swedish crowns. ${ }^{2}$ Locals as well as people far from Västmanland saw the involvement of individuals through social media to support those in need. They offered shelter for people and space for both big and small animals, such as cows and horses, using social media. ${ }^{3}$ Sweden is not alone. Social media and other online communication tools are becoming a subject of great interest in mass emergency response (Hughes, Lise, Palen, \& Anderson, 2014; Palen, Vieweg, Liu, \& Hughes, 2009), which helps build new, perhaps solid social networks and temporary communities.

\section{Crime, farm crime, and rural crime}

The definition of crime varies by country, but all definitions share the same core. According to the Swedish Penal Code, "Crime is legally an act in contravention of a provision of law for which there is a prescribed punishment" (Ministry of Justice, 1994). The Swedish definition of crime is similar to the one in the Oxford English Dictionary (2009): "an offense or a criminal offense and is an act harmful not only to some individual, but also to the community or the state (a public wrong), which is forbidden and punishable by law." Some are directed to persons, other properties, 


\section{Introduction}

the state or society, and the environment. Overall, to be classified as a crime, the intention has to be part of the action; that is, an act of wrongdoing must usually be accompanied by the intention to commit the wrong.

Rural crimes are crimes that take place in rural contexts. Some are ordinary crimes, such as burglary and fights (crimes against property or a person), while others are more specifically related to the opportunities for crime that only occur in rural areas. Rural crime includes farm crime, such as theft of tractors or cattle, often property crimes against the unit of production (farm), but also acts that cause harm to nature or wildlife, also called environmental crimes (excessive levels of air, water, or soil pollution, deforestation in natural reserves, injuries of animals and wildlife). Some violations fit the definition of harmful actions but may not be considered a crime; however, every crime violates the law. Chapter 8 discusses in detail examples and definitions of these rural crimes.

\section{Harm and social harm}

A few definitions of harm are "physical or psychological injury or damage," "wrongdoing, evil," and "to injure physically, morally, or mentally" someone and something (Collins English Dictionary, 2003). A portion of the research on social harm that is pertinent to this book focuses on whether a social harm is labeled a crime as well as the degree to which that crime or social harm is visible (see e.g., Davies, Francis, \& Wyatt, 2014). The authors suggest that uncovering crime may not be easy; realizing that it is a criminal act and defining it as such depends on a number of factors. There must be witnesses, detection, and recognized victims. It is this dynamic that allows crimes and harm to have different degrees of invisibility that stem from the interplay of this range of factors, which overlap and interact to decrease or increase the level of visibility. In this book, the term "harm" is associated with damaging acts against nature and wildlife; some acts are registered as crimes by the police or environmental inspectors, while others refer to cases of destruction of rivers or forests or maltreatment of or injury to animals or wildlife witnessed, but in some cases captured only by radio or newspaper journalists.

\section{Safety and security}

The concept of "security" is rooted in the Latin term securitas, associated with "peace of mind, freedom from care, and also freedom from danger" (Ceccato, 2013b). Wiebe et al. (2014) defines security as "being free from the risk of being assaulted and security from feeling afraid of being assaulted," while safety is "an individual's perception of how safe they are from the risk of being victimized." Safety and security are contested concepts that remain somewhat arbitrary and open to debate as different disciplines attach different meaning to them. Some use these terms in completely opposite ways (Ceccato \& Newton, 2015) or broaden it by including the notion of harm to individuals and nature, such as victimization by natural hazards. 
Although in this book safety and security are used interchangeably, security will be more often associated with the risk of being the victim of a crime, while safety will be linked to an individual's perception of how safe they are from the risk of being victimized. Individuals may also be affected by other anxieties caused by multi-scale factors that may lead individuals to declare feeling unsafe. Thus, perceived safety in this book is an umbrella concept that involves a number of feelings, from fear of crime to emotions and anxieties that may be triggered by current uncertainties and threats that are far from the individual, family, or community scale (see for instance, Giddens, 1991, 2014). In Chapter 6 potential causes of these emotions are discussed in detail in the rural context.

\section{Gender and intersectionality}

Safety is defined here as being dependent on the individual and the groups to which they might belong (Giddens, 1991). With regards to victimization and perceived safety, this book puts a special focus on those individuals and groups whose safety is overlooked by police and official statistics. Among the individual factors affecting the perception of safety, gender is perhaps the most important. Violence against women in domestic settings is just one example of a situation that demands a nuanced approach to rural safety. On this subject, see the work done by criminologists in DeKeseredy (2015). As rural is concerned, what does it mean to adopt a gender-informed approach to safety?

Gender can be defined in the context of gender mainstreaming, which is defined by the UN (1997) in terms of a set of strategies for making women's as well as men's concerns and experiences an integral part of policies and programs in all societal spheres, so that women and men benefit equally so inequality is not perpetuated. The main goal is to achieve a society with better gender equality, assuming from the start that there are many spheres of life in which women are at a great disadvantage to men. In the context of safety, this principle should mean that victimization and fear should not depend on the basic characteristics of an individual, such as gender or age. Worldwide, much of what is in place in terms of intervention practices, for instance by the UN Women's initiative Safe Cities (UN, 2013), as the name illustrates, focuses on violence against women in public places and is predominantly linked to women in urban areas (but see UN Women, 2014).

Both in research and practice, though, it is important not to overgeneralize between groups and not to overemphasize the gender dimension on top of other individual qualities. A range of factors can influence victimization and fear of crime, including age, gender, ethnicity, economics, behavior, culture, and selfidentity. The complexity of gender and safety requires paying attention not just to being a woman or a man but also to the intersections between gender and age, ethnicity, financial resources, individual experiences, and culture, to name a few. These overlaps are essential considerations, because the way they take shape in an individual creates different outcomes: one being of discrimination, weakness, and disadvantage, as opposed to integration, power, and advantage. More 
interesting, the combination may also have a synergic effect, for instance, being a woman from a minority ethnic group and unemployed.

Intersectionality has been around for some time and became popular particularly in sociology in the late 1960s and early 1970s. It has been adapted to criminology by studies devoted to inequality in victimization, particularly in the United States (e.g., Barak, Leighton, \& Flavin, 2010; Peterson \& Krivo, 2005). The concept of "intersectionality," "the interaction of multiple identities and experiences of exclusion and subordination," as defined by Davis (2008, p. 67), can also be associated with the environmental justice movement and scholarships that emerged in the 1970s and 1980s in the United States (e.g., Bullard, 1983 ) and flourished since then as a predominately "urban-centric" field (but see e.g., Bell and Braun, 2010). Chapters 7 and 10 exemplify how these dimensions cross over to emerge as layers of vulnerability and discrimination recognized by experiences discussed in the case of Sami youth, and non-Swedish women.

\section{Othering, otherness, and discrimination}

Differences between residents and newcomers in a rural community can be maximized by both groups, giving expression to us-them feelings. In the literature, this has been associated to different terms, such as "othering," the process of perceiving or portraying someone or something as fundamentally different from oneself or a group to which the one pertains (as part of othering or the process of transforming a difference into otherness). Sandercock (2005) suggests that fear of others is often one cause of the animosity between newcomers and locals, previously identified as an expression of the fear of the unknown. This can take different shapes, from fear and neglect, to discrimination and violence of different types (Carrington, Hogg, \& McIntosh, 2011; Cloke \& Little, 1997; Philo, 1997b; Scott et al., 2012).

Garland and Chakraborti (2006) discuss the process of racial discrimination in rural England against the idyll myth of the rural communities being neighborly and close-knit with strong feelings of belonging. They suggest that this process obscures and marginalizes the experiences of minority ethnic residents who can often feel excluded from village life. Garland and Chakraborti (2006) argue that the intersection of rurality with notions of Englishness and "whiteness" serves to reinforce further the process of marginalization. For a detailed discussion, see Chakraborti and Garland (2011). This book, in particular Chapters 6 and 10, illustrates the process of othering and discrimination in the rural Swedish context.

\section{The emergence of rural crime and community safety in criminology}

Rural criminology is a multidisciplinary and interdisciplinary field of research (Ceccato, 2015). This cannot be better illustrated than by the special issue on "crime and community safety" recently published by the Journal of Rural 
Studies in 2015, volume 39. Researchers from different traditions provided a variety of articles, each contributing new research to their own particular disciplines while together approaching the issues of crime and safety in rural communities. These studies stemmed from different, sometimes similar, epistemological and paradigmatic traditions in the social and natural sciences. Their approaches varied, from positivistic, to critical and feminist, from quantitative modeling, to the many different qualitative methods. The volume resulted in an intricate composition of themes at different analytical levels and depth, from country-based to individual-level studies. This book bypasses that rich body of previous theories and methods and instead sets out theories that are more focused on and therefore more pertinent to the scope of this book. The objective of this chapter is to translate these theories into an integrated theory-driven conceptual framework within which crime and community safety in rural areas can be further analyzed. None of these theories is without criticism, and none has been developed strictly for the purpose of explaining crime and safety in rural contexts. Worth noting is the special attention given to rural places as a criminogenic element in the interplay between offenders and victims. If the emphasis is on the environment where crime takes place, then reducing crime, or making places safer, requires initiatives that focus on reducing crime opportunities at those places by taking into account their particular contexts.

\section{Theories that support the study of crime in rural studies}

Theories in rural crime research have focused predominantly on the spatial dimension of crime (Donnermeyer, 2007), which is not surprising, as almost any consideration of what "rural" means must consider its geographical dimensions (Hobbs, 1994). Crime opportunities are not random; nor are patterns in fear of crime. One explanation is that crime reflects people's whereabouts, where people spend time. For urban settings, environmental criminology research is populated by examples of how crime geography reflects people's routine activities over time (e.g., Cohen \& Felson, 1979; Sherman, Gartin, \& Buerger, 1989). But how do these principles work in rural areas? Do rural areas present a particular set of situations unique from other non-rural environments?

According to crime point pattern theory, it is the interaction of the location of potential targets and the criminal's awareness or activity space that culminates in particular patterns of crime occurrence. Brantingham and Brantingham (1984, p. 362) indicate that this happens because individuals' whereabouts affect their chances of coming in contact with other individuals, some of them offenders. In defining the concept of "opportunity space," these authors suggest that offenders learn through experience or social transmission the clues that are associated with "good" victims or places where they can attack. A node is an activity space where people carry out major activities and spend most of their time, for example the office, home, or local pub. It is suggested that around these activity nodes individuals develop awareness spaces, around the settings they become acquainted with. Paths are the routes that individuals take between these nodes. 
In rural context they can be the streets individuals take when moving around in the village or when commuting to the neighboring village - a principle that applies both for victims and offenders.

Another concept of crime pattern theory is that of "edges," beyond which persons are unfamiliar with the space. Crimes occur where and when the immediate environment makes the offender feel familiar and safe to act, whilst victims are unfamiliar with certain environments and the risks they face, for instance, when they are traveling in areas they do not routinely go. In rural contexts, edges can be perceived as the boundaries of the village, or for young people or children, it can be their own street. These ideas are corroborated by decades of evidence that indicate that individuals commit crime not far from their current (and previous) place of residence and that their journey is affected by different types of geographical barriers (Bernasco, 2010; Porter, 1996; White, 1932; Wiles \& Costello, 2000) but see, for example, Townsley and Sidebottom (2010).

Whether an offender travels far is perhaps not as interesting as asking whether crimes in rural areas are committed by locals and against local residents (Ceccato \& Dolmén, 2011; Mawby, 2015) or whether people take advantage of barriers to commit crime elsewhere. For instance, Mawby (2015) examined police data and victim surveys from Cornwall, England, to investigate victims' and offenders' status: long-term residents; recent arrivals; second-home owners; temporary residents, e.g., seasonal workers; visitors, e.g., holidaymakers; or people there on business. Findings provide little evidence whether the offenders or victims were nonresidents or residents. Ceccato and Haining (2004) assessed offenders' mobility at the southern Swedish border after the opening of the Öresund bridge linking Sweden and Denmark and found different results. Data on the total number of suspects committing offenses by citizenship indicates a slight increase since 2000 in the total number of offenders in the Öresund region for all citizenships selected (Danes, Germans, Poles, Latvians, Lithuanians, Estonians). According to the National Police Board, despite the fact that data on offenders' citizenship does not provide an accurate indication of offenders' mobility patterns, since we do not know their home address, the data constitutes "a good proxy." For example, 75 percent of Polish citizens and 45 percent of Danish citizens arrested for committing crime in Swedish Öresund in 1998 did not live in the region. Among Polish citizens, a large number came from deprived areas in northwest Poland. The analysis, however, was not limited to rural areas but covered the whole region of Öresund with large urban agglomerations such as Malmö.

Two other interesting concepts are "crime attractors" and "crime generators" (Brantingham \& Brantingham 1995). These concepts help us think about differences in crime concentrations in rural contexts, though they may be more appropriate to explain the geography of crime in urban environments. Crime generators are places where large numbers of people are present, for reasons unrelated to criminal motivation. This convergence in time and space creates new and unexpected criminal opportunities for violence and property crimes. Crime attractors are places that breed crime and many criminal opportunities and may be well known to offenders. 
Criminally motivated individuals are drawn to such locations, thus increasing the number of crime and disorder events. For instance, some types of crimes are concentrated in border municipalities or in some parts of them (crime attractors); others are concentrated in villages that receive a large inflow of population during the summer (crime generators). Yet, not all places that attract many people are criminogenic. For certain types of offenses, fewer people around and alert makes the environment more criminogenic, for instance for burglary, rape, domestic violence, dumping of oil in nature. This leads us to reason about the necessary conditions for crime, here indicated by routine activity theory. The theory draws attention to the environmental or situational context that influences the offender's decision to commit rape.

Crimes depend on the convergence in space and time of motivated offenders, suitable targets, and the absence of capable guardians (Cohen \& Felson, 1979). The "right place" poses opportunities for crime, which for theft might be a crowded place, for rape a secluded place, or where either guardianship is not present or not willing or able to intervene. Felson (2006) exemplifies that guardianship can be produced by multiple actors. Some are what is called handlers who control potential offenders (e.g., guards, police, and the rural community in general). Others are managers, who control places (e.g., rural transients, those who collect milk at the entrance of a farm daily), and guardians, who control targets (e.g., the farmers themselves). For targets, there are two types of guardians: formal guardians whose responsibility is to protect people and property from crime, such as police officers and security guards, and informal guardians, including friends and others who are at the same place as the target. Donnermeyer (2007) indicates that more so than other place-based theories, routine activity theory includes changes of circumstances in its framework. Such changes can be economic, social, or cultural changes that modify the number of motivated offenders and/or suitable targets and increase or decrease guardianship; crime levels will change accordingly. For instance, the location of buildings may affect thefts (close to the road as opposed to far from the view of transients), dogs or other farm security measures may reduce the chances for thefts by improving guardianship on a farm, or thefts might increase if prices on livestock rapidly increase.

As in crime point pattern theory, routine activity principles rely on people's everyday life rhythms: morning, noon, afternoon, night, weekdays and weekends, winter and summer. This means that any type of human activity is limited by the amount of time available each day. Time is both a necessary condition and a constraint for an activity. In this sense, committing a crime (or falling victim of it) is an example of an activity like any other. As Felson (2006, pp. 6-7) indicates:

The daily life of a city provides the targets for crime and removes them. The sleeping, walking, working, and eating patterns of offenders affect the metabolism of crime... We must study these rhythms of life if we wish to understand crime. 
Whilst routine activity theory defines the necessary conditions for a crime to occur, it does not define the sufficient conditions. Crime does not happen just because victims and offenders happen to share similar spatial awareness and converge at a certain place and time. An understanding of the sufficient conditions for crime begins by considering each individual's perception of their safety and how it affects their movement patterns. Between the residents of different neighborhoods, there are large differences in perceptions of safety that affect individuals' daily movements and people's capacity to exercise social control. The offender may avoid these areas, and, as a consequence, crime becomes concentrated in other areas. Yet, crime varies within rural areas, just as rural areas themselves vary from one another (Lowe, Marsden, Murdoch, \& Ward, 2012). Equally, within rural areas, towns appear to experience higher levels of crime than villages and smaller settlements (Mawby, 2015). Community size and population density are not the only factors that affect crime (Carrington, 2007; Ceccato \& Dolmén, 2011; Donnermeyer et al., 2006; Felson, 2013; Kaylen \& Pridemore, 2013b; Mawby, 2007). Decades of evidence from urban environments have shown that socially disorganized neighborhoods experience disproportionately more crimes.

Social Disorganization Theory (Bursik, 1999; Kornhauser, 1978; Sampson, 1986; Shaw \& McKay, 1942) has provided part of the theoretical foundation for many studies that focus on the impact of area (and neighborhood) characteristics on crime. Shaw and McKay linked neighborhood social disorganization (areas that combine deprivation, residential instability, and ethnic diversity) to delinquency and crime. The mechanisms linking socially disorganized neighborhoods and crime relate to people's inability to exercise social control in their neighborhoods and solve jointly experienced problems. In neighborhoods with high population turnover (perhaps linked with people's fear of crime in that area), guardianship decreases further, enhancing the ecological conditions associated with crime. Social disorganization theory suggests that structural disadvantage breeds crime and that offending occurs when impaired social bonds are insufficient to encourage or enforce legitimate behavior and discourage deviant behavior.

Bursik (1999) defines social disorganization as an inability of community members to achieve shared values or to solve jointly experienced problems. In other words, these communities lack social capital. Social capital has been associated with social bonds that create networks that bring a collective benefit to neighborhood residents. Communities with high stocks of social capital are more effective in exerting informal social control through the establishment and maintenance of norms. However, high social capital does not necessarily result in collective benefits. Social capital can be bonding, or exclusive, or bridging, or inclusive (Putnam, 2000, p. 22). Groups may exclude or subordinate other groups (Ceccato \& Haining, 2005). Deller and Deller (2012) assessed the role of social capital in explaining patterns of rural larceny and burglary crime rates. They find consistent evidence that higher levels of social capital tend to be associated with lower levels of rural property crime rates. 
Nevertheless, Sampson et al. (1997), suggest that action to restrict crime does not necessarily demand "strong local social ties or associations." Action by the group may happen where personal ties and social networks are weak. Collective efficacy is the group-level term used by Sampson et al. (1997) to refer to the situation where there are shared expectations within the group and a willingness to engage in processes of social control.

Two versions of empirical applications of social disorganization theory are recognized in the international literature: the structural antecedents model and the systemic model (Donnermeyer, 2014). Donnermeyer writes that the structural antecedents model relies on aggregated properties of a specific area (neighborhood, town, city, village, mostly coming from censuses and other sources) as factors affecting crime and delinquency (police recorded data). In the systemic model, the antecedents are only "proxies" and are mediated by more direct indicators of internal social cohesion and control through local networks.

The first test of the antecedents model was the one by Osgood and Chambers (2003). They hypothesized that, as in urban areas, in small towns and rural communities, systems of relationships are relevant to crime and delinquency. The authors found that one or more of the social disorganization variables were significantly associated with arrest rates for all of the violent offenses other than homicide. Rates of crime and delinquency were associated with residential instability, ethnic diversity, and family disruption. For example, a higher proportion of female-headed households was strongly associated with higher rates of arrest for violent offenses except homicide. This was interpreted as the burden of single parenting and joint supervision of children. However, surprisingly, the authors did not find any link between poverty and rates of delinquency. One of the interpretations is that poverty does not strike in rural areas as it does in urban areas, particularly metropolitan areas. Thus, the authors concluded that a high rate of rural poverty that does not affect the delinquency rate appears to be consistent with social disorganization theory.

However, the results of a similar study conducted by Kaylen and Pridemore (Deller \& Deller, 2010, 2011; Kaylen \& Pridemore, 2011, 2012, 2013a, 2013b) indicate that the association between social disorganization and violence in rural areas is sensitive to how the dependent variable is measured. Authors suggest a search for other data sources and not to rely solely on official crime data from rural areas when testing sociological and criminological theories. On the latter point, they are convincing in Kaylen and Pridemore (2013a), using the British Crime Survey. The study examines data from respondents living in rural areas in 318 postcode sectors and is declared to be the first test of the full social disorganization model in the literature on rural crime. Again, their findings call for a reassessment of the conclusions drawn about how social disorganization and crime are related in rural communities.

Donnermeyer (2014) suggests therefore that the same social networks and social capital that produce social cohesion and collective efficacy can simultaneously constrain some crimes even as the occurrence of other crimes is facilitated. The author suggests that there are multiple forms of social organization, or 
collective efficacy (instead of social disorganization or anti-efficacy) at the same place and same time, allowing individuals to simultaneously participate in multiple networks, some of which may be criminal. For a detailed discussion of social organization and crime, see Donnermeyer and DeKeseredy (2013), Donnermeyer, Scott, and Carrington (2013).

Cultural differences in values, norms, and beliefs held by members of groups or subgroups may also explain variations in crime. The idea of the existence of a subculture for crime has been associated with high rates of violence, particularly in the United States (Messner \& Rosenfeld, 1999). In the United States, the evidence for this subculture of violence is the concentration of high rates of murder that have characterized the south. The subculture of violence theory is a controversial one (Farrington, Loeber, \& Southamer-Loeber, 2003) but has been suggested to be part of the explanation for large regional differences in violence elsewhere (Salla, Ceccato, \& Ahven, 2011). Chapter 9 in this book refers to the subculture of crime and violence that characterizes motorcycle gangs in rural Sweden, such as Hells Angels and Bandidos, and that is intertwined with the local way of life in some municipalities.

The influence of area characteristics on individual offender behavior depends on their mobility. Individuals are mobile and spend time in many settings and environments with differing criminogenic characteristics. Situational action theory (SAT) offers a process-based explanation of offending and identifies the sufficient conditions for a crime to occur. This framework attempts to explain why individuals commit crime. It comprises four features: an individual, a setting, a situation, and an action. SAT states that criminal acts in a place are the outcome of a perception-choice process initiated by the interaction between the individual's crime propensity and the discouragements to crime that are present in the area. The outcome (offending or otherwise) depends on two sets of factors: (1) the individual's own moral rules and self-control and (2) the extent to which society's moral rules are enforced in that place (Wikström et al., 2010, p. 56). This means that a rural environment that enforces law-abiding behavior would be less propitious to promote offending. A remaining question is whether rural areas present a distinct set of situations for an individual living there that are different from those for individuals living in urban environments.

\section{Macro theories of crime and rural transformations}

Macro theories relating crime to society's structure and organization, such as anomie theory, have also been adopted in rural studies to aid in understanding the levels and patterns of crime. These transformations in rural areas are thought not to be detached from processes suggested by theories of rural change (Ilbery \& Bowler, 1998; Marsden, 1998; Ramsey, Abrams, \& Evans, 2013). Woods (2011) presents in detail the process of rural transformation, from rural as a space of production, to contemporary products of exploitation of the countryside that characterize the global economy. Similar processes of rural change occur under multiple forces at an unprecedented pace elsewhere, involving rapid and 
unexpected changes that are bound to have an impact at the micro level, that is, in rural communities. For example, Ravera et al. (2014), drawing upon six context-specific case studies from Asia, Latin America, and Europe, examine the current drivers and pathways of rural change by analyzing examples of new ruralities that are emerging as responses across different world regions. Sweden has also shown signs of rural change as a result of a period of major restructuring under the recent development of the globalized economy (Ilbery \& Bowler, 1998; Marsden, 1998). Johansson, Westlund, and Eliasson (2009) suggest that this "new rurality" is imposing new patterns of demographic, socioeconomic, and environmental differentiation at both local and regional levels.

Crime is argued to be linked to rural change, because profound transformations are expected to produce a chronic state of deregulation in society, in which valued goals are reduced and society fails to place normative limits on people's behavior. Durkheim (1897) was the first to suggest that rapid social change creates anomie, which can have a negative impact on society and is linked to increases in crime. Individuals take advantage of anomic conditions, or the insecurity status resulting from a breakdown of standards and values in society. Using the United States as a background, Merton (1938) suggests that anomie is the result of a lack of adequate means to fulfill society's culturally sanctioned goals conceptualized as "the American Dream." Thus, "normlessness" transforms into a lack of or weakening of social controls which are fundamental for preventing crime. Another line of inquiry considers the relationship of strain to criminal behavior (Agnew, 1999). A growing literature has evolved in the past decade linking societal transformations to crime (Ceccato, 2008; Ceccato \& Haining, 2008; Kim \& Pridemore, 2005; Liu, 2005; Salla et al., 2011) but rarely focusing specifically on rural areas (but see Freudenburg \& Jones, 1991; Rephann, 1999). Ceccato (2008) examines how demographic, socioeconomic, land use, and institutional factors relate to crime geography and levels in the Baltic countries after the fall of the Soviet Union and in the transition to a market economy. The author also found that indicators of municipalities social structure, such as divorce rate, predict the variation in crime better than other indicators, such as land use and economic covariates. In rural contexts, Freudenburg and Jones (1991) assessed crime in rural communities that undergo rapid population change due to various types of economic development.

The effect of societal changes may be moderated by the existing safety net, promoted by pro-social institutions. It was Messner and Rosenfeld $(1994,1997)$ who suggested social institutions tend to be devalued in comparison to economic institutions (which they called "institutional anomie") and lose their power so that criminogenic conditions increase. However, they also suggest that such an effect can be moderated by social institutions in places that invest in formation of social capital. Chapter 5 focuses on shifts in the geography of crime, from the 1990 s to the 2000s, and some of these principles are used as a reference. A redistribution of the urban population to larger cities has affected the labor market and affected regional income distribution (Johansson et al., 2009). These changes are expected to have an impact on crime dynamics that might be moderated by pro-social institutions. 


\section{Principles of fear of crime and perceived safety}

The nature of perceived safety (or the lack thereof - fear) is a phenomenon affected by multi-scale factors (Day, 2009; Los, 2002; Wyant, 2008). Some factors that affect perceived safety are generated locally, and perhaps they are felt as tangible, whilst others may be more difficult to assess but still affect individuals' anxieties and may be produced in all possible geographical dimensions, from global to local. Perceived safety involves more than just fear of crime.

Warr (2000, p. 453) defines fear as "an emotion, a feeling of alarm or dread caused by awareness or expectation of danger." Thus, an increase in crime would hypothetically affect perceived safety. Yet, this simplistic causal relationship rarely matches, as the fear of crime refers to the fear of being a victim of crime, as opposed to the actual probability of being a victim of crime. Fear can be multidimensional, as an individual can fear for oneself (personal fear) and fear for others (altruistic fear) whose safety the person values.

Chapter 6 includes a detailed discussion of why perceived safety (fear of crime and overall anxieties) varies across groups and across rural areas, looking for answers behind individual, local, and global factors. The chapter also separately reviews possible causes of variations in perceived safety, but, of course, in reality perceived safety is bound to be a result of intersections of all these factors: gender, previous victimization, familiarity, physical environment, signs of disorder and crime, mobility patterns, social cohesion and collective efficacy, othering, macro-societal changes, commodification of security, and media.

\section{Crime prevention in theory}

There are several ways to prevent crime from occurring. One is to intervene before an individual has the choice to consider crime as an alternative. For that, social crime prevention addresses individual- and family-level factors that might lead to offending. Individual-level factors, such as attachment to school and involvement in pro-social activities, decrease the probability of criminal involvement but rely on long-term intervention. Other types of intervention focus on individuals that are already at risk and are in need of targeted intervention.

Crimes cannot be properly explained, or effectively prevented, without a deep understanding of the environments in which they occur (Smith \& Cornish, 2006). These interventions adopt techniques focusing on reducing the opportunity to commit a crime. Some techniques include increasing the difficulty of crime, increasing the risk of crime, and reducing the rewards of crime (Clarke, 1997). Situational crime prevention aims to affect the motivation of criminals by means of environmental and situational changes and is based on three elements: (1) increasing the perceived difficulty of crime; (2) increasing the risks; and (3) reducing the rewards. Thus, this book focuses on situational crime prevention but also looks at general actions in rural community policing. As suggested by Yarwood (2015), community policing may engage several actors: police, voluntary organizations, citizens, and private actors. Whilst police are typically 
assigned to act in specific geographical areas in their jurisdiction, policing may have less distinctive territorial boundaries, as actors are not necessarily restricted on a territorial basis, which is the way the police work to cover large rural municipalities in rural Sweden, particularly in the north. These types of crime prevention strategies are considered in detail in this book in Chapters 12, 13, and 14.

\section{The making of criminological research in rural areas}

Quoting Young (2011, p. 58), Joe Donnermeyer made an important point in his presentation at the 2014 Stockholm workshop on crime and community safety. Donnermeyer noted the importance of theories in rural studies, regardless of the methods and tools a researcher may adopt: "It is not more and fancier statistical testing that will solve the problems of numbers in the social sciences. Rather it is theory and conceptualization ... that give numbers relevance, utility, and their place." This is certainly accurate, for any field of science. In rural studies, this is especially important as the rural is, and always has been, a dynamic and diverse space (Woods, 2011, p. 293). Theories and conceptual frameworks have to allow for the diversity and complexity of rurality. This complex rural reality is what guides us through the process of inquiry.

In this book, Crime Science principles (see e.g., Laycock, 2005; Pawson \& Tilley, 1997) have been adopted to guide the process of inquiry. I have attempted to illustrate why rural areas are worth investigating by taking into account the variability of the term "rural." To do that, principles from Crime Science can be useful, as they promote the integration of theories from different disciplines for understanding patterns of crime and perceived safety. Two examples here illustrate this point. The first step, before outlining the theory to be used, is to define the aim of the inquiry. For instance:

$1 \quad$ Why does farm crime cluster in certain areas of the country? or

2 What do offenders and victims know about the situational conditions of farm crime?

While the first research question aims at generalizing the criminogenic conditions of farm crime across the country, the second one aims at teasing out thieves' and farmers' interpretations (of the target and offender) of particular criminal opportunities (situational conditions) and their respective actions for crime perpetration/prevention. Most researchers would agree that despite being two similar research questions, in practice they demand different theoretical frameworks and different perhaps complementary, at best case, overlapping - research methods and datasets.

The second step in the process of inquiry is to adopt a set of theories that support the search for answers to the research questions. In example (1), routine activity theory may be useful in the interpretation of patterns of farm crime, together with theories of social (dis)organization. Here quantitative indicators may be regressed against rates or cases of police-recorded farm crimes at municipal levels. 
In example (2), a combination of positivistic and critical sociological theories is desirable to frame the research question, relying on situational crime prevention and the theory of "othering" analyzed through interviews with farmers and thieves. Each research question is set with specific context descriptors, for instance, temporal and spatial. It is worth noting that spatial analysis can become an integral part of the research process in these examples: in (1) by mapping and statistically analyzing spatial patterns of police-recorded statistics, and in (2) by allowing detailed mental maps drawn by both thieves and farmers. Thus, the argument put forward here is that the research is not data-, method-, or theorydriven. Instead, as common sense as it sounds, it is the (rural) reality materialized by the research questions that guides the researcher's decision-making through the process. These overlapping research questions exemplify different realities of rural seen through the eyes of the researcher. Both are worth investigating, as they are bound to produce different outcomes, providing complementary pictures of the rural. By acknowledging this plurality, Woods (2011) observes that our studies give only partial glimpses of what rural is. He recognizes that it is exactly this complexity of the rural that makes its study challenging and exciting, with much to explore. This leads us to the next issue.

The idea of obtaining a single definition of rural, rural areas/spaces, or rurality - something that has become clearer through this book - appears to be fruitless. Yet, the recognition that rural areas are composed of a diverse set of communities with different characteristics and needs that share a number of qualities and challenges compels us forward in an attempt to capture the nature of rural areas from a particular viewpoint. In this book, rural areas were framed from a criminological perspective using different theoretical frameworks. How was this done?

The focus is on the plurality of crime, victimization, and practices in crime prevention. The book also considers a number of ways of tackling these subject areas, from top-down to bottom-up research approaches. One example of this is the analysis of violence against women. On one hand, official statistics showed general concentrations of gendered violence across the country and within rural areas; on the other hand, violence was investigated considering specific cases of women who, for instance, were brought to the country by their partners and later fell by the partner's brutality. Another example is the assessment of crime prevention practices using cross-triangulation of three data sources: from top-down, a database from the Swedish National Council for Crime Prevention; from bottom-up, an email survey sent to representatives of local crime prevention groups in all rural municipalities in Sweden and interviews with more than 40 agents working with crime prevention in eight rural municipalities. A similar approach was taken when assessing youth-related problems and crime against nature. Overall, this combination of perspectives was successful in illustrating sometimes diverging, other times complementary, views of rural safety.

The multi-method and multi-data approach adopted in this book requires the object of study to be fixed in relation to particular temporal (cross-sectional or longitudinal) and spatial references, as well as other contexts that might be 
relevant to the studied phenomena. Comparative frameworks can be useful to establish some external reference to a specific case. As Chapters 4-14 illustrate, this approach calls for a development of research and practice in rural crime and community safety that goes beyond the borders of research fields and theoretical perspectives.

The novelty of this approach is to allow the combination of interdisciplinary research questions (for instance, from Psychology and Criminology) into a framework of analysis that shares the same field of inquiry but takes different perspectives. Another advantage is to welcome a diverse array of paradigmatic perspectives, from positivistic to critical perspectives in Criminology (see e.g., Donnermeyer \& DeKeseredy, 2013), into a single framework. Traditionally, such diverse approaches are thought to be incompatible and require different research processes. They may do so, but these paradigmatic starting points can, when pursued in parallel, produce complementary views of the same rural reality.

\section{Issues of measuring crime and perceived safety in a rural context}

Ten different types of data were used for the analysis in Chapters 4-14 of this book (Table 3.2). The use of multi-methods was a necessity, given the diverse types of data sources. The array of quantitative, qualitative, and spatial methods has proved useful, as the combination allowed new ways to explore new relationships between different scales of analysis of a single-problem (for instance, violence against women or crime against the environment), nation-wide or casestudy-based analysis. The use of maps and spatial analysis is a red thread in Chapters 4 to 14 .

\section{Table 3.2 Types of data}

\begin{tabular}{ll}
\hline Data type & Coverage \\
\hline $\begin{array}{l}\text { Official police data } \\
\text { National victims surveys and farmers } \\
\quad \text { victimization survey }\end{array}$ & $\begin{array}{l}\text { Sweden, municipality, x,y coordinates } \\
\text { Sweden }\end{array}$ \\
$\begin{array}{l}\text { Demographic, socio-economic and land use data } \\
\text { in GIS }\end{array}$ & Sweden \\
$\begin{array}{l}\text { Database on local crime prevention projects } \\
\text { (BRA) }\end{array}$ & Sweden (selected municipalities) \\
$\begin{array}{l}\text { Health statistics/hospitalization of women } \\
\text { victims of violence by hospitals }\end{array}$ & Hospitals \\
$\begin{array}{l}\text { Women's data shelter database for Sweden } \\
\text { CrimeStoppers Sweden database on crime } \\
\text { incidence }\end{array}$ & Sweden by women's shelter \\
$\begin{array}{l}\text { Media coverage analysis, newspaper } \\
\text { Email survey } \\
\text { Interviews face-to-face }\end{array}$ & $\begin{array}{l}\text { Sweden } \\
\text { Sweden (selected municipalities) }\end{array}$ \\
\hline
\end{tabular}

Source: Halfacree (1993). 
The most important data sources for this book were recorded police data and national victim surveys, but without other sources the book would not exist. Each of these crime data sources is reliable for most crimes, but none is free of problems. In this section the data quality issues with police-reported statistics and victimization surveys are discussed. Some of the issues discussed below are particularly problematic in rural areas and are discussed in detail in each chapter. Police statistics are based on administrative data (or $x-y$ coordinates) generated by reports of crime to the police, and national victimization surveys show the prevalence and incidence of crime based on crime victim surveys.

\section{Police-recorded data}

Data reliability is an important issue when working with police crime data or crime-victim survey data. Underreporting is a known cause of lack of reliability in databases of police-recorded offenses. Traditionally, levels of reporting vary with the type of offense and its seriousness. This is particularly important in rural areas, as an individual may face traveling long distances to report a crime. Internationally, burglary and theft of vehicles are far more likely to be reported than many other types of offenses, such as domestic violence. Burglary and theft are often more reported for insurance purposes, while domestic violence is not because the offender is someone whom the victim knows well (see Chapter 10 for more). There are also indications that the offense reporting level may be underestimated in areas where people think that it is not worthwhile reporting them. Chapters 5 and 8 illustrate the low reporting rates for certain types of crimes among farmers in Sweden, as they believe that reporting is "a waste of time."

Other problems of data quality occur during the process of recording. Ceccato (2005) observes that this can be caused by the lack of information about the event from the victim (not knowing exactly where the offense took place) or by the police officer failing to record the event properly (failing to record the exact location). This may create extra cases in those particular locations, which may, if not identified in advance, contribute to "false hot spots." In rural environments, it is common to have crime associated with a single point linked to the center of a polygon; often that location does not match the exact location of the offense (for instance, behind a barn, garage, main house). This inaccuracy can be related to the place of the offense or the time it happened (if the victim was away when it happened). When there is no available information about the time that the event occurred, estimating a range of hours is often the common practice (e.g., 12:00-16:00). However, for analysis purposes, this limits any space-time trend assessment. Aoristic models (Ratcliffe, 2010; Ratcliffe \& McCullagh, 1998) are commonly used to interpolate timerelated data that are missing.

Despite the fact that there are conventions for recording offenses in many countries, including Scandinavia, differences still occur in practice. Problems of data quality relate to the lack of systematization of procedures when recording an 
offense. For example, an assessment of the Swedish offense database for Skåne (southern Sweden) has shown that large municipalities often have better offense records than small ones. After an evaluation of thousands of records in small towns, Ceccato and Haining (2004) found that the victims or police officers in small municipalities only approximate the offense's location (such as close to the park, in front of the bus station), which contributes to the poor quality of records.

Inaccuracies in crime data can also be introduced during geocoding. Geocoding is the process of matching records in two databases: the offense addresses database (without map position information) and the reference street map with $x-y$ coordinates. The quality of the geocoding process depends very much on the quality of the offense records, the quality of the address dictionary, the chosen method for geocoding (matching), and the experience of the geocoder. Ceccato and Snickars (2000) estimate, for instance, that about 25 percent of all offenses committed in a district were attached not to their "real locations" but to the polygons' centroids of the local commercial area.

Although they constitute a minority, one group of offenses have places or times unknown by the victim or are hard to pinpoint, as people were in motion when the crime happened. A typical example is when a crime takes place on a bus or train traveling between point $\mathrm{A}$ and point B. Stations and bus stops are often the reference for these types of crimes but may be indicators of potential false hot spots. A good way to identify potential false hot spots is to check them for long-term patterns. If they are false, they may disappear over time, because the way the offense is reported may change, affecting the choice of "dumping site" (Ceccato, 2005).

In some cases, the location of crime is not geographical but virtual and is difficult to tackle. In many cases such as fraud over the telephone, the victim and offender may never meet. On the Internet, residents living in rural, remote areas in Sweden are potentially as vulnerable to these sorts of crimes as their counterparts living in the Swedish capital, assuming they have Internet access and a computer. The crime can also be committed against a large number of people simultaneously. On a general level, one can speak of a trend away from theft offenses toward more fraud and scams, constituting a new type of crime often using ICT (BRA, 2014).

\section{National victims surveys}

Most general methodological problems in victimization surveys are related to sampling, measurement, and inference problems (Schneider, 1981) - but they are not limited to these. There are numerous methodological pitfalls in the use of survey data to study violence against women or to analyze fear of crime, for instance (Farrall, Bannister, Ditton, \& Gilchrist, 1997; Schwartz, 2000). Schwartz and Pitts (1995) indicate that the major problems in analyzing violence against women are definitional problems, operationalization of concepts, recall bias, underreporting, question order, external validity, and the sex and ethnicity of interviewers. 
In terms of sampling, an important problem is the issue of representation. Serious crimes are a relatively rare event. Thus, samples have to be of a considerable size to generate enough incidents of any particular type to permit detailed and meaningful analysis. This is particularly a problem when rural areas are concerned. However, a number of strategies can be used (e.g., weighting) depending on the response rate by groups and classes. See Chapter 10 for the details of this particular problem in the case of the Swedish victims surveys for violence against women in rural areas.

Another challenge when using crime victim survey data is that most research in this area may face problems because of what they assume with the data available. There is a long tradition among criminologists to use casual models using data from a survey cross-sectionally instead of a panel design. The problem grows when victimization is set as an independent variable, because the direction of causality may be difficult to ascertain. The problem is particularly accentuated when these variables designate behaviors and attitudes and are collected at a certain point in time, whereas the assumed victimization occurred prior to the interview. Schneider (1981) noted, for instance, that when victimization is set as an independent variable it is easier to deal with.

The third type of problem with crime victimization surveys is how far one can make inferences for a certain variable. It is difficult to determine how much of the variance in the victimization variable is true variance and how much is error. Whether the error is produced by a lack of reliability or by a lack of validity is not particularly important; what is important is that measurement error can influence the conclusions drawn from research studies.

In summary, the challenges in using police-recorded statistics and/or crimevictim survey data include not only the data itself but the way in which these data resources are utilized and theoretically framed. For instance, in ecological analysis there is a constant risk of so-called ecological fallacy, which occurs when correlated, aggregated values over a specific geographical area are erroneously related to the individual level. There is also the risk that maps, such as the ones presented in this book, may be used to create images that cannot be generalized for the whole group, and a distorted map may turn out to be a tool for exclusionary practices instead of providing a basis for more just actions (Ceccato, 2013a, pp. 20-21). In practice, the quality of data impacts on the quality of safety provided, in a best case scenario guiding evidence-based practices that can be shared by policing actors.

\section{Rural Sweden: The study area}

Why study Sweden? Sweden is an interesting case study for several reasons. Sweden is a Scandinavian and Nordic country (Figure 3.1a) with a milder climate than most other European countries. Most of the country is icebound from December to April, which limits, for instance, agriculture.

According to Eurostat, in 2014 there were 9.7 million people in Sweden. Of Sweden's 9.7 million residents, about 200,000 live in remote rural areas. Far 


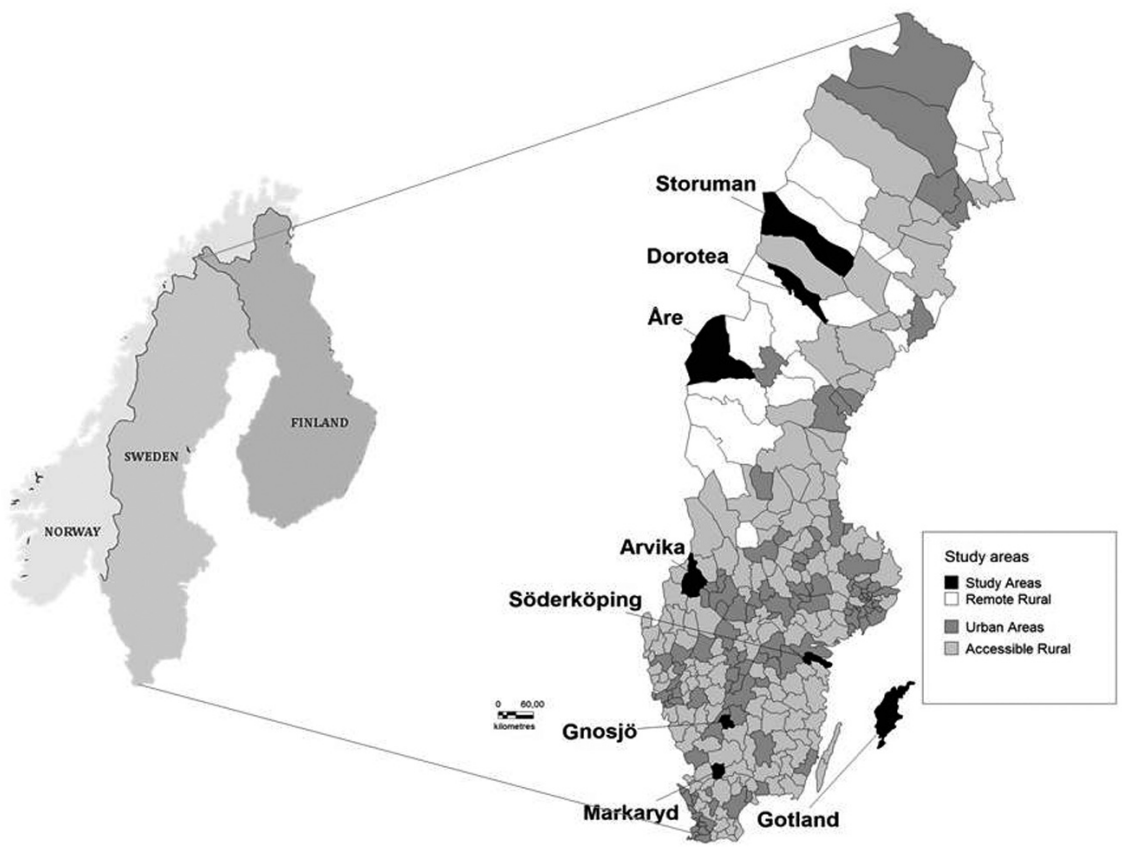

(a)

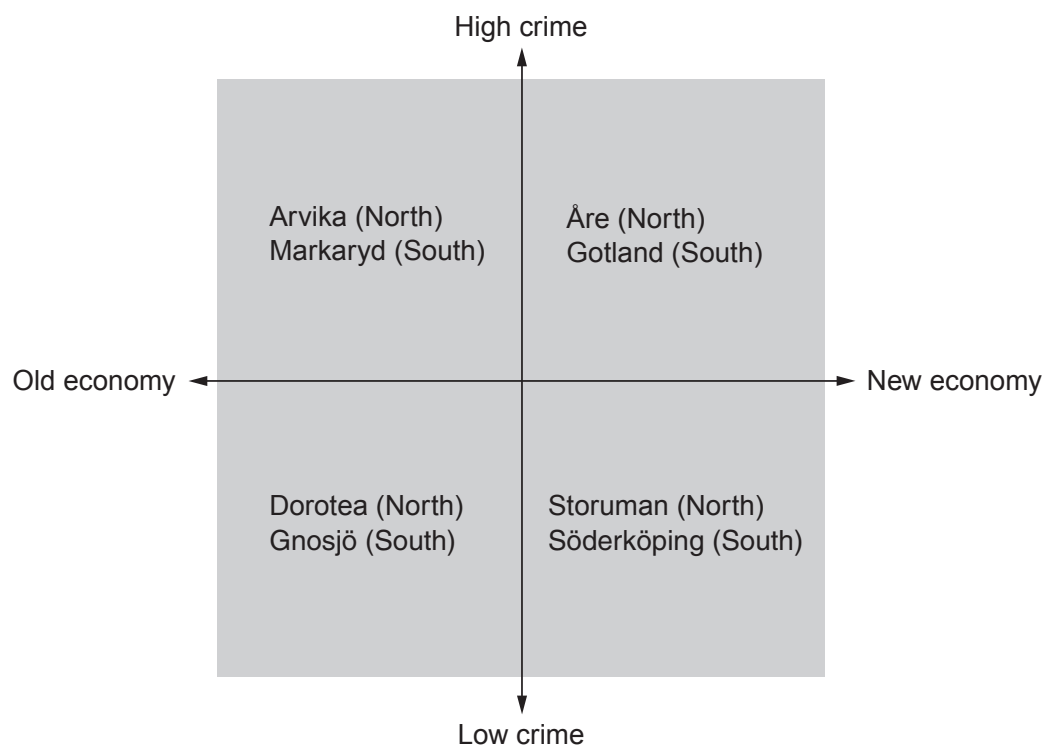

(b)

Figure 3.1 Municipalities in Sweden by type (a) and selection of eight municipalities for evaluating local crime prevention (b). 


\section{Introduction}

from being a homogeneous entity, rural in this book is considered here as a diverse set of communities with different characteristics and needs but that share a number of qualities and challenges. In Sweden, rural municipalities can be of two types: Remote Rural (RR) are areas more than 45 minutes by car from the nearest urban neighborhood with more than 3,000 inhabitants and Accessible Rural (AR), is composed of areas 5-45 minutes by car from urban locations with more than 3,000 inhabitants. Municipalities with more than 3,000 inhabitants and reachable in five minutes by car are regarded as Urban Areas (UA) ${ }^{4}$ (Swedish National Rural Development Agency, 2008) (Figure 3.1a). Although problematic because it does not incorporate other dimensions of rurality, this definition reflects the municipalities' population size and accessibility, which are important criminogenic factors.

From an European perspective, Sweden is a sparsely populated country (22 inhabitants per $\mathrm{km}^{2}$; the corresponding figure for Denmark is 125). There are 290 municipalities (Kommun) in Sweden, with an average population size of 31,000 inhabitants (from a minimum of 2.6 up to 766,000 inhabitants). In most chapters of this book municipalities are the unit of analysis since it is the smallest administrative unit and it is at this level that most indicators are available for comparisons at national level. There is a clear north-south divide in the population distribution: most remote rural municipalities are located in the mid-northwest of the country (22), whereas accessible rural (156) and urban (112) areas are found in the mid-South.

In addition, Sweden constitutes an interesting case study because most of the literature on crime and perceived safety in rural areas is based on case studies from North American and British studies. There is a need to extend the empirical evidence to include cases studies such as those in Sweden, which are embedded in more socially oriented forms of capitalism. Like the United States and most Western European countries, Sweden has transitioned from being rural and agrarian to urban and industrial/post-industrial state, which has affected not only crime levels but also the organization of basic services, including the police. Yet, welfare system principles play an important role in defining policies in Sweden, but with a more market oriented economy, the country has shown signs of 'rural change' that has imposed different demographic, socio-economic and cultural differentiation at both local and regional levels. In the last few decades the regional population redistribution have decreased but the tendency is towards concentration to a few regions with a decrease of population in rural areas. These developments - as described above - can be linked to the dynamics of crime. In addition, about 14 percent of the Swedish population was born in another country, the 10 largest groups coming from Finland, Iraq, Poland, the former Yugoslavia, Iran, Somalia, Germany, Turkey, and Denmark. Although they tend to be concentrated in the three largest cities in Sweden, certain foreign-born groups may be overrepresented in some parts of the country and/or towns. Foreign-born individuals are more often exposed to crime than natives, which has a direct impact on their perceived safety and quality of life, with marginal differences between urban and rural areas. 
Studies reporting experiences with crime prevention (CP) in rural areas are relatively few in the international literature in comparison with those in urban areas. This book makes a contribution to this knowledge basis by looking at $\mathrm{CP}$ in rural areas particularly to deal with youth problems, farms and environmental crimes, and gendered violence. In 2010 there were $300 \mathrm{CP}$ groups across the country. In order to evaluate $\mathrm{CP}$ in rural areas, a group of eight municipalities were selected representing the new and the old economy chosen based on the percentage of the active population employed in service sectors (Åre, Gotland, Storuman, and Söderköping) and in traditional sectors of the economy (Arvika, Markaryd, Dorotea, and Gnosjö), respectively (Figure 3.1b). High and low crime levels are defined based on the relative rural regional average rate: high-crime municipalities are those with crime rates above the average and low-crime municipalities show a rate below the rural average (Åre and Gotland from the new economy and Arvika and Markaryd from the traditional economy are high-crime municipalities; low-crime municipalities are Storuman and Söderköping from the modern economy and Dorotea and Gnosjö from the old economy). By studying Sweden, this book characterizes rural crime, perceived safety and crime prevention in Scandinavian rural contexts, which was until recently inexistent in the international literature.

\section{Concluding remarks}

This chapter highlights some of the most important theoretical markers for the book. It starts with basic definitions in crime and community safety in rural areas with the intention to provide a conceptual framework for the book. Key theories in criminology are discussed in relation to their theoretical power to support the analysis and complexities of rural areas. This includes a short review of the main types of crime prevention models portrayed in Chapters 11 to 14. Finally, a number of issues related to data quality and implications of data sources for the analysis of rural crime, perceived safety, and crime prevention are highlighted, with the focus on official police statistics and national crime victims surveys.

A number of points are worth keeping in mind when reading the next chapters. First, the search for a singular definition of "rural" is illusory, but this does not mean that rural is an indefinable theoretical entity. In reality, rural areas are composed of a diverse set of communities with different characteristics and needs that share a number of qualities and challenges. Their qualities might be worth investigating taking into account both the relativism of the term associated to what is considered to be "rural" according to those that produce and experience the rural (its reflexivity). Rural must be regarded in relation to time and spatial references as well as contexts in which it occurs. This calls for the development of research and practice about rural and safety that crosses the current boundaries between fields, disciplines, and theoretical perspectives.

Another important point is that none of the theories discussed in this chapter is without criticism, and none was developed for the purpose of explaining 


\section{Introduction}

crime, perceived safety, and crime prevention in rural contexts. However, all these theoretical principles have the potential to support the analysis of rural areas in the next chapters, from routine activity theory to situational crime theory, as well as macro theories such as institutional anomie.

Perceived safety involves more than just fear of crime but it can be captured as such through crime victim surveys. How one defines safety is a result of intersections of many factors, some being individual (such as age, gender, sexual identity, disability, previous victimization, familiarity with an environment, mobility), others being related to qualities attributed to the environment where he or she is embedded (such as signs of disorder and crime, social cohesion, and collective efficacy) or macro-scale processes (such as the media, natural hazards, global threats). Safety depends on the individual and the groups' characteristics to which they belong. With regards to victimization and perceived safety, special focus is given in this book to those individuals and groups whose safety is often overlooked by police and official statistics. The book adopts a gender-informed approach to safety, avoiding generalization and assessing how victimization intersects with other types of individual characteristics.

Emphasis is given to the environment where crime takes place. This means that reducing crime, or making places safer, requires initiatives that focus on reducing crime opportunities at those places by taking into account their particular contexts. Knowledge of what works and what does not work in rural contexts is necessary. Problems in police data and data from crime victims' surveys are unlikely to be resolved in the short term, by researchers or practitioners, but the use of multi-data and multi-methods, as in this book, will likely become a worthwhile alternative for rural criminology.

\section{Notes}

1 For a complete discussion of the different types of definitions, see, for example, Halfacree $(1993,2006)$ and Woods $(2005,2011)$.

2 Dagens Nyheter, Försäkringsbranschen: Förbered Sverige bättre för extremväder, retrieved September 11, 2014, from www.dn.se/ekonomi/forsakringsbranschen-forberedsverige-battre-for-extremvader/.

3 Södermanlands Nyheter, Stort engagemang för skogsbranden i sociala medier, retrieved August 5, 2014, from www.sn.se/nyheter/sormland/1.2537146.

4 An alternative way to classify Swedish rural areas was suggested by Statistics Sweden (H-regions), with six classes of municipalities, from large urban areas to remote rural ones, based on their geographical and economic homogeneity.

\section{References}

Agnew, R. (1999). A general strain theory of community differences in crime rates. Journal of Research in Crime and Delinquency, 36(2), 123-155.

Barak, G., Leighton, P., \& Flavin, J. (2010). Class, race, gender, and crime: The social realities of justice in America. Plymouth: Rowman \& Littlefield.

Barclay, E., Scott, J., Hogg, R., \& Donnermeyer, J. (Eds.). (2007). Crime in rural Australia. Sydney: Federation Press. 
Bell, D. (1997). Anti-idyll: Rural horror. In P. Cloke \& J. Litte (Eds.), Contested countryside cultures: Otherness, marginalisation and rurality (pp. 94-108). London: Routledge.

Bell, S. E., \& Braun, Y. A. (2010). Coal, identity, and the gendering of environmental justice activism in central Appalachia. Gender and Society, 24(6), 794-813.

Bernasco, W. I. M. (2010). A sentimental journey to crime: Effects of residential history on crime location choice. Criminology, 48(2), 389-416.

Bosworth, G., \& Somerville, P. (2014). Introduction. In G. Bosworth \& P. Somerville (Eds.), Interpreting rurality: Multidisciplinary approaches (pp. 1-11). Oxford: Routledge.

Brantingham, P., \& Brantingham, P. (1984). Patterns in crime. New York: Macmillan.

Brantingham, P., \& Brantingham, P. (1995). Criminality of place: Crime generators and crime attractors. European Journal on Criminal Policy and Research, 3, 1-26.

Brottsförebyggande rådet - BRÅ (National Council of Crime Prevention). (2014). Police recorded statistics. Stockholm: BRÅ.

Bullard, R. D. (1983). Solid waste sites and the black Houston community. Sociological Inquiry, 53(2-3), 273-288.

Bursik, R. J. (1999). The informal control of crime through neighborhood networks. Sociological Focus, 32(1), 85-97.

Carrington, K. (2007). Crime in rural and regional areas. In J. F. D. E. Barclay, J. Scott, \& R. Hogg (Eds.), Crime in rural Australia (pp. 27-43). Sydney: Federation Press.

Carrington, K., Hogg, R., \& McIntosh, A. (2011). The resource boom's underbelly: Criminological impacts of mining development. Australian and New Zealand Journal of Criminology, 44(3), 335-354.

Ceccato, V. (2005). Tools in the spatial analysis of offences: Evidence from Scandinavian cities. In M. Campagna (Ed.), GIS for sustainable development (pp. 267-287). Boca Raton, CA: CRC, Taylor \& Francis.

Ceccato, V. (2007). Crime dynamics at Lithuanian borders. European Journal of Criminology, 4(2), 131-160.

Ceccato, V. (2008). Expressive crimes in post-socialist states of Estonia, Latvia and Lithuania. Journal of Scandinavian Studies in Criminology and Crime Prevention, 9(1), 2-30.

Ceccato, V. (2012). The urban fabric of crime and fear. Dordrecht/New York/London: Springer.

Ceccato, V. (2013a). Integrating geographical information into urban safety research and planning. Proceedings of the ICE - Urban Design and Planning, 166, 15-23.

Ceccato, V. (2013b). Moving safely: Crime and perceived safety in Stockholm's subway stations. Plymouth: Lexington.

Ceccato, V. (2015). Guest editorial. Journal of Rural Studies, 37.

Ceccato, V., \& Dolmén, L. (2011). Crime in rural Sweden. Applied Geography, 31(1), $119-135$.

Ceccato, V., \& Dolmén, L. (2013). Crime prevention in rural Sweden. European Journal of Criminology, 10, 89-112.

Ceccato, V., \& Haining, R. (2004). Crime in border regions: The Scandinavian case of Öresund, 1998-2001. Annals of the Association of American Geographers, 94, 807-826.

Ceccato, V., \& Haining, R. (2005). Assessing the geography of vandalism: Evidence from a Swedish city. Urban Studies, 42, 1637-1656.

Ceccato, V., \& Haining, R. (2008). Short and medium term dynamics and their influence on acquisitive crime rates in the transition states of Estonia, Latvia and Lithuania. Applied Spatial Analysis and Policy, 1(3), 215-244.

Ceccato, V., \& Newton, A. (Eds.). (2015). Safety and security in transit environments: An interdisciplinary approach. Basingstoke: Palgrave. 
Ceccato, V. A., \& Snickars, F. (2000). Adapting GIS technology to the needs of local planning. Environment and Planning B: Planning and Design, 27(6), 923-937.

Chakraborti, N., \& Garland, J. (Eds.). (2011). Rural racism. Abingdon/New York: Routledge.

Clarke, R. V. (1997). Situational crime prevention: Successful case studies. Monsey, NY: Willow Tree.

Cloke, P., \& Little, J. (1997). Contested countryside cultures: Otherness marginalisation and rurality. London: Routledge.

Cohen, L. E., \& Felson, M. (1979). Social change and crime rate trends: A routine activity approach. American Sociological Review, 44, 588-608.

Collins English Dictionary. (2003). Harm. Complete and Unabridged, Collins. Retrieved December 2, 2014, from www.thefreedictionary.com/harm.

Crang, M., \& Thrift, N. (2000). Introduction. In M. Crang \& N. Thrift (Eds.), Thinking Space (pp. 1-30). London: Routledge.

Davies, P., Francis, P., \& Wyatt, T. (2014). Taking invisible crimes and social harms seriously. In P. Davies, P. Francis, \& T. Wyatt (Eds.), Invisible crimes and social harms (pp. 1-25). Basingstoke: Palgrave Macmillan.

Davis, K. (2008). Intersectionality as buzzword: A sociology of science perspective on what makes a feminist theory successful. Feminist Theory, 9(1), 67-85.

Day, K. (2009). Being feared: Masculinity and race in public space. In M. L. S. Farrall (Ed.), Fear of crime: Critical voices in an age of anxiety (pp. 82-107). New York: Routledge-Cavendish.

DeKeseredy, W., Muzzatti, S., \& Donnermeyer, J. (2014). Mad men in bib overalls: Media's horrification and pornification of rural culture. Critical Criminology, 22(2), 179-197.

DeKeseredy, W. S. (2015). New directions in feminist understandings of rural crime and social control. Journal of Rural Studies (in press).

Deller, S., \& Deller, M. (2010). Rural crime and social capital. Growth and Change, 41(2), 221-275.

Deller, S., \& Deller, M. (2011). Structural shifts in select determinants of crime with a focus on rural and urban differences. Western Criminology Review, 12(3), 120-138.

Deller, S., \& Deller, M. (2012). Spatial heterogeneity, social capital, and rural larceny and burglary. Rural Sociology, 77(2), 225-253.

Donnermeyer, D., \& DeKeseredy, W. S. (2013). Rural criminology. Abingdon: Routledge.

Donnermeyer, J. (2007). Locating rural crime: The role of theory. In E. Barclay, J. Donnermeyer, J. Scott, \& R. Hogg (Eds.), Crime in rural Australia (pp. 15-26). Annandale: Federation Press.

Donnermeyer, J. (2012). Rural crime and critical criminology. In W. S. DeKeseredy \& M. Dragiewicz (Eds.), Routledge handbook of critical criminology (pp. 290-302). Abingdon: Routledge.

Donnermeyer, J., Scott, J., \& Carrington, K. (2013). How rural criminology informs critical thinking in criminology. International Journal for Crime, Justice and Social Democracy, 2(3), 69-91.

Donnermeyer, J. F. (2014). The social organization of rural america and crime. Paper presented at Rural Crime and Community Safety, Stockholm.

Donnermeyer, J. F., Jobes, P., \& Barclay, E. (2006). Rural crime, poverty and rural community. In W. S. DeKeseredy \& B. Perry (Eds.), Advancing critical criminology: Theory and application (pp. 199-213). Oxford: Lexington Books.

Durkheim, E. (1897). Suicide: A study in sociology. New York: Free Press. 
Farrall, S., Bannister, J., Ditton, J., \& Gilchrist, E. (1997). Questioning the measurement of the gear of crime: Findings from a major methodological study. British Journal of Criminology, 37(4), 658-679.

Farrington, D., Loeber, R., \& Southamer-Loeber, M. (2003). How can the relationship between race and violence be explained? In D. F. Hawkins (Ed.), Violent crime: Assessing race and ethnic differences (pp. 213-237). Cambridge: Cambridge University Press.

Felson, M. (2006). Crime and nature. Thousand Oaks, CA: Sage.

Felson, M. (2013). Crime's impingement in space. In S. Ruiter, W. Bernasco, W. Huisman, \& G. Bruinsma (Eds.), Eenvoud en verscheidenheid: Liber amicorum voor Henk Elffers (pp. 341-355). Amsterdam: NSCR \& Afdeling Criminologie Vrije Universiteit Amsterdam.

Fernback, J. (2007). Beyond the diluted community concept: A symbolic interactionist perspective on online social relations. New Media and Society, 9(1), 49-69.

Freudenburg, W. R., \& Jones, R. E. (1991). Criminal behavior and rapid community growth: Examining the evidence 1. Rural Sociology, 56(4), 619-645.

Frey, W. H., \& Zimmer, Z. (2001). Defining the city. In R. Paddison (Ed.), Handbook of urban studies (pp. 14-35). London: Sage.

Garland, J., \& Chakraborti, N. (2006). "Race", space and place: Examining identity and cultures of exclusion in rural England. Ethnicities, 6(2), 159-177.

Giddens, A. (1991). Modernity and self-identity: Self and society in the late modern age. Cambridge: Polity Press.

Giddens, A. (2014). Turbulent and mighty continent: What future for Europe? Cambridge: Polity.

Groves, R. (2011). Rural and suburban America: When one definition is not enough. Seattle, WA: Washington University.

Halfacree, K. (1993). Locality and social representation: Space, discourse and alternative definitions of the rural. Journal of Rural Studies, 9(1), 23-37.

Halfacree, K. (2006). Rural space: Constructing a three-fold architecture. In P. Clocke, T. Marsden, \& P. Mooney (Eds.), Handbook of rural studies (pp. 44-62). London: Sage.

Hobbs, D. (1994). The context of rising rates of rural violence and substance abuse: The problems and potential of rural communities. In S. M. Blaser, J. Blaser, \& K. Pantoja (Eds.), Perspectives on violence and substance use in rural America (pp. 115-124). Wilmington, NC: North Carolina Regional Educational Laboratory.

Hogg, R., \& Carrington, K. (1998). Crime, rurality and community. Australian and New Zealand Journal of Criminology, 31(2), 160-181.

Hogg, R., \& Carrington, K. (2006). Policing the rural crisis. Sydney: Federation Press.

Hoggart, K. (1990). Let's do away with rural. Journal of Rural Studies, 6(3), 245-257.

Holloway, R., \& Kneafsey, L. (2000). Reading the space of the farmers' market: A preliminary investigation from the UK. Journal Sociologia Ruralis, 40(3), 285-299.

Hughes, A., Lise, A. A., Palen, L., \& Anderson, K. N. (2014). Online public communications by police \& fire services during the 2012 Hurricane Sandy. Paper presented at the Proceedings of the SIGCHI Conference on Human Factors in Computing Systems, Toronto, Ontario, Canada.

Ilbery, B., \& Bowler, I. (1998). From agricultural productivism to post-productivism. In B. Ilbery (Ed.), The geography of rural change (pp. 53-83). Harlow: Addison Wesley Longman.

Johansson, M., Westlund, H., \& Eliasson, K. (2009). The "new rurality" and entrepreneurship: Attributes influencing enterprise propensity in rural Sweden. Paper presented at the Congress of Regional Science Association International, Lodz, Poland. 


\section{Introduction}

Kaylen, M., \& Pridemore, W. A. (2012). Systematically addressing inconsistencies in the rural social disorganization and crime literature. International Journal of Rural Criminology, 1(2), 148.

Kaylen, M. T., \& Pridemore, W. A. (2011). A reassessment of the association between social disorganization and youth violence in rural areas. Social Science Quarterly, 92(4), 978-1001.

Kaylen, M. T., \& Pridemore, W. A. (2013a). The association between social disorganization and rural violence is sensitive to the measurement of the dependent variable. Criminal Justice Review, 38(2), 169-189.

Kaylen, M. T., \& Pridemore, W. A. (2013b). Social disorganization and crime in rural communities: The first direct test of the systemic model. British Journal of Criminology, 53(5), 905-923.

Kim, S.-W., \& Pridemore, W. A. (2005). Social change, institutional anomie and serious property crime in transitional Russia. British Journal of Criminology, 45(1), 81-97.

Kornhauser, R. (1978). Social sources of delinquency. Chicago, IL: University of Chicago Press.

Lambert, J. (2013). Digital storytelling: Capturing lives, creating community (4th ed.). New York: Routledge.

Laycock, G. (2005). Defining crime science: New approaches to detecting and preventing crime. In N. T. Melissa \& J. Smith (Eds.), Crime science (pp. 3-24). Cullompton, Devon: Willan Publishing.

Liepins, R. (2000). New energies for an old idea: Reworking approaches to "community" in contemporary rural studies. Journal of Rural Studies, 16(1), 23-35.

Liu, J. (2005). Crime patterns during the market transition in China. British Journal of Criminology, 45(5), 613-633.

Los, M. (2002). Post-communist fear of crime and the commercialization of security. Theoretical Criminology, 6(2), 165-188.

Lowe, P., Marsden, T., Murdoch, J., \& Ward, N. (2012). The differentiated countryside. London/New York: Routledge.

Mahon, M. (2007). New populations; shifting expectations: The changing experience of Irish rural space and place. Journal of Rural Studies, 23(3), 345-356.

Marsden, T. (1998). New rural territories: Regulating the differentiated rural spaces. Journal of Rural Studies, 14(1), 107-117.

Marsden, T. (2008). Agri-food contestations in rural space: GM in its regulatory context. Geoforum, 39(1), 191-203.

Mawby, R. (2015). Exploring the relationship between crime and place in the countryside. Journal of Rural Studies (in press).

Mawby, R. I. (2007). Crime, place and explaining rural hotspots. International Journal of Rural Crime, 1, 21-43.

Melamid, A. (1967). Von Thunen's isolated state: An English edition of Der Isolierte Staat by Johann Heinrich von Thunen; Carla M. Wartenberg; Peter Hall; central places in southern Germany by Walter Christaller; Carlisle W. Baskin. Geographical Review, 57(4), 574-576.

Merton, R. (1938). Social structure and anomie. American Sociological Review, 3, 672-682.

Messner, S., \& Rosenfeld, R. (1994). Crime and the American dream. Belmont, CA: Wadsworth.

Messner, S. F., \& Rosenfeld, R. (1997). Political restraint of the market and levels of criminal homicide: A cross-national application of institutional anomie theory. Social Forces, 75, 1393-1416. 
Messner, S., \& Rosenfeld, R. (Eds.). (1999). Social structure and homicide: Theory and research (Vols. 27-34). London: Sage.

Ministry of Justice. (1994). Brott, Lag (1994:458). C.F.R. § kap. $1 \S$ Brottsbalken Regeringskansliets rättsdatabaser (in Swedish). Retrieved April, 9, 2015 from https:// lagen.nu/1962:700\#K1P1.

Osgood, D. W., \& Chambers, J. M. (2003). Community correlates of rural youth violence. Juvenile Justice Bulletin, May, 12.

Oxford English Dictionary (2009). Crime. Oxford: Oxford University Press.

Owen, S., \& Carrington, K. (2015). Domestic violence (DV) service provision and the architecture of rural life: An Australian case study. Journal of Rural Studies (in press).

Palen, L., Vieweg, S., Liu, S. B., \& Hughes, A. L. (2009). Crisis in a networked world: Features of computer-mediated communication in the April 16, 2007, Virginia tech event. Social Science Computer Review, 27(4), 467-480.

Pawson, R., \& Tilley, N. (1997). Realistic evaluation. London: Sage.

Peterson, R. D., \& Krivo, L. J. (2005). Macrostructural analyses of race, ethnicity, and violent crime: Recent lessons and new directions for research. Annual Review of Sociology, 31, 331-356.

Philo, C. (1997a). Across the water: Reviewing geographical studies of asylums and other mental health facilities. Health and Place, 3(2), 73-89.

Philo, C. (1997b). Of other rurals. In P. Cloke \& J. Little (Eds.), Contested countryside cultures: Otherness marginalisation and rurality (pp. 19-48). London: Routledge.

Porter, M. (1996). Tackling cross border crime. London: Home Office.

Putnam, R. (2000). Bowling alone: The collapse and revival of American community. New York: Simon \& Schuster.

Ramsey, D., Abrams, J., Clark, J. K., \& Evans, N. J. (2013). Rural geography - rural development: An examination of agriculture, policy and planning, and community in rural areas. Journal of Rural and Community Development, 8(1), i-v.

Ratcliffe, J. (2010). Crime mapping: Spatial and temporal challenges. In A. R. Piquero \& D. Weisburd (Eds.), Handbook of quantitative criminology (pp. 5-24). New York: Springer.

Ratcliffe, J. H., \& McCullagh, M. J. (1998). Aoristic crime analysis. International Journal of Geographical Information Science, 12(7), 751-764.

Ravera, F., Scheidel, A., dell'Angelo, J., Gamboa, G., Serrano, T., Mingorría, S., Cabello, V., Arizpe, N., \& Ariza, P. (2014). Pathways of rural change: an integrated assessment of metabolic patterns in emerging ruralities. Environment, Development and Sustainability, 16(4), 811-820.

Reissman, L. (1964). The urban process: Cities in industrial societies. New York: Free Press of Glencoe.

Rephann, T. J. (1999). Links between rural development and crime. Papers in Regional Science, 78(4), 365-386.

Rhodes, W., \& Conly, C. (1981). Crime and mobility: An empirical study. In P. J. Brantingham \& P. L. Brantingham (Eds.), Environmental criminology (pp. 167-188). Beverly Hills, CA: Sage.

Rogers, E. M., Burdge, R. J., Korsching, P. J., \& Donnermeyer, J. (1988). Social change in rural societies (3rd ed.). Englewood Cliffs, NJ: Prentice Hall.

Salla, J., Ceccato, V., \& Ahven, A. (2011). Homicide in Estonia. In M. C. A. Liem \& W. A. Pridemore (Eds.), Handbook of European homicide research: Patterns, explanations, and country (pp. 421-437). New York/Dordrecht/Heidelberg/London: Springer.

Sampson, R. J. (1986). Crime in cities: The effects of formal and informal social control. Crime and Justice, 8, 271-311. 
Sampson, R. J., Raudenbush, S. W., \& Earls, F. (1997). Neighborhoods and violent crime: A multilevel study of collective efficacy. Science, 277(5328), 918-924.

Sandercock, R. J. (Ed.). (2005). Difference, fear and habitus: A political economy of urban fear. Aldershot: Ashgate.

Schneider, A. L. (1981). Methodological problems in victim surveys and their implications for research in victimology. Journal of Criminal Law and Criminology, 72(2), 818-838.

Schwartz, M. D. (2000). Methodological issues in the use of survey data for measuring and characterizing violence against women. Violence Against Women, 6(8), 815-838.

Schwartz, M. D., \& Pitts, V. L. (1995). Exploring a feminist routine activities approaches to explaining sexual assault. Justice Quarterly, 12, 9-31.

Scorzafave, L. G., Justus, M., \& Shikida, P. F. A. (2015). Safety in the global south: Criminal victimization in Brazilian rural areas. Journal of Rural Studies (in press).

Scott, J., Carrington, K., \& McIntosh, A. (2012). Established-outsider relations and fear of crime in mining towns. Sociologia Ruralis, 52(2), 147-169.

Shaw, C. R., \& McKay, H. D. (1942). Juvenile delinquency and urban areas. Chicago, IL: University of Chicago Press.

Sherman, L. W., Gartin, P. R., \& Buerger, M. E. (1989). Hot spots of predatory crime: Routine activities and the criminology of place. Criminology, 27(1), 27-56.

Shortall, S., \& Warner, M. (2012). Rural transformations: Conceptual and policy issues. In M. Shucksmith, D. Brown, S. Shothall, J. Vergunst, \& M. Warner (Eds.), Rural transformations and rural policies in the US and UK (pp. 3-18). New York: Routledge.

Smith, M. J., \& Cornish, D. B. (2006). Secure and tranquil travel: Preventing crime and disorder on public transport. London: Routledge.

Smith, N. (1984). Uneven development. Oxford: Blackwell.

Thrift, N. (1996). Spatial formations. London: Sage.

Townsley, M., \& Sidebottom, A. (2010). All offenders are equal, but some are more equal than others: Variation in journeys to crime between offenders. Criminology, 48(3), 897-917.

Tönnies, F. (1887). Gemeinschaft und Gesellschaft. Leipzig: Fues's Verlag. (Translated, 1957 by Charles Price Loomis as Community and society, East Lansing, MI: Michigan State University Press.)

United Nations - UN. (1997). Report of the economic and social council for 1997. A/52/3, General Assembly, 52nd Session. New York: United Nations Department of Economic and Social Affairs.

United Nations - UN. (2013). Creating safe public spaces. Retrieved April 9, 2015, from www.unwomen.org/en/what-we-do/ending-violence-against-women/creating-safepublic-spaces.

UN Women. (2014). Safe cities global initiatives. UN, 2. Retrieved April 9, 2014, from www.unwomen.org.

van Leeuwen, E. S. (2010). Urban-rural interactions towns as focus points in rural development. Heidelberg/Dordrecht/London/New York: Springer-Verlag.

Warr, M. (2000). Fear of crime in the United States: Avenues for research and policy. Criminal Justice and Behavior, 4, 451-489.

Websdale, N., \& Johnson, B. (1998). An ethnostatistical comparison of the forms and levels of woman battering in urban and rural areas of Kentucky. Criminal Justice Review, 23, 161-196.

Weisheit, R. A., \& Donnermeyer, J. F. (2000). Changes and continuity in crime in rural America. In G. LaFree (Ed.), Criminal justice 2000: The nature of crime, continuity and change (pp. 309-357). Washington, DC: US Department of Justice. 
Weisheit, R. A., Falcone, D. N., \& Wells, L. E. (2006). Crime and policing in rural and small-town rural America. Prospect Heights, IL: Waveland Press.

Weisheit, R. A., Wells, L. E., \& Falcone, D. N. (1994). Community policing in small town and rural America. Crime and Delinquency, 40(4), 549-567.

White, R. C. (1932). The relation of felonies to environmental factors in Indianapolis. Social Forces, 10(4), 498-509.

Wiebe, D. J., Richmond, T. S., Poster, J., Guo, W., Allison, P. D., \& Branas, C. C. (2014). Adolescents' fears of violence in transit environments during daily activities. Security Journal, 27(2), 226-241.

Wikström, P.-O., Ceccato, V., Hardie, B., \& Treiber, K. (2010). Activity fields and the dynamics of crime. Journal of Quantitative Criminology, 26(1), 55-87.

Wiles, P., \& Costello, A. (2000). The "road to nowhere": The evidence for travelling criminals (p. 207). London: Home Office Research Study.

Woods, M. (2005). Defining the rural. In Rural geography (pp. 3-16). London: Sage.

Woods, M. (2011). Rural. London/New York: Routledge.

Wyant, B. R. (2008). Multilevel impacts of perceived incivilities and perceptions of crime risk on fear of crime: Isolating endogenous impacts. Journal of Research in Crime and Delinquency, 45(1), 39-64.

Yarwood, R. (2015) Lost and hound: The more-than-human networks of rural policing. Journal of Rural Studies (in press).

Yarwood, R., \& Edwards, B. (1995). Voluntary action in rural areas: The case of neighbourhood watch. Journal of Rural Studies, 11(4), 447-459.

Young, J. (2011). The criminological imagination. Cambridge: Polity Press. 